\title{
Multiple myeloma associated with osteosclerotic and osteolytic lesions
}

\author{
Osteosklerotik ve osteolitik lezyonlarla ilişkili multipl myelom
}

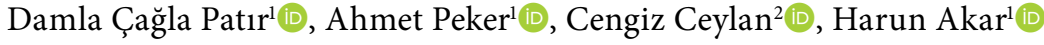 \\ ${ }^{1}$ Department of Internal Medicine, University of Health Sciences, Tepecik Training and Research Hospital, Izmir, Turkey \\ ${ }^{2}$ Department of Hematology, University of Health Sciences, Tepecik Training and Research Hospital, Izmir, Turkey
}

Multiple myeloma (MM) is a hematologic malignancy associated with an uncontrolled and monoclonal increase in plasma cells, the mature form of B lymphocytes. In most patients, monoclonal paraproteins are detected in serum and urine. ${ }^{[1]}$ The disease is characterized by lytic bone lesions, presence of $\mathrm{M}$ protein in serum and urine, and plasma cell infiltration in the bone marrow. Lymphadenopathy is rarely encountered. Multiple myeloma usually presents with fatigue, renal failure, bone pain, and weight loss. ${ }^{[2]}$ Osteoblastic lesions are rare in multiple myeloma cases. In patients with multiple myeloma with osteoblastic lesions, this condition usually occurs with POEMS syndrome (polyneuropathy, organomegaly, endocrinopathy, monoclonal gammopathy, and skin changes). ${ }^{[3]}$ In this article, we hope to share a rare case of multiple myeloma associated with simultaneous osteolytic and osteosclerotic lesions.

An 82-year-old male patient admitted to our outpatient clinic with complaints of weight loss, generalized chest pain and tenderness, and generalized body pain. Examinations revealed anemia and elevated erythrocyte sedimentation rate and the patient was admitted to the internal medicine ward for further examination and treatment. Physical examination showed fever of $37.6^{\circ} \mathrm{C}$, blood pressure $130 / 62 \mathrm{mmHg}$, pulse $72 \mathrm{bpm}$ and respiratory rate was $18 \mathrm{bpm}$. The patient had no organomegaly. Peripheral lymphadenopathy was not detected. Respiratory sounds were normal. Cardiac examination showed heart sounds were rhythmic and there was no additional sound or murmur. The patient had diffuse pain and tenderness in his chest region. The laboratory findings of the patient were as follows: Glucose: $119 \mathrm{mg} / \mathrm{dL}$, Creatinine: $1.1 \mathrm{mg} / \mathrm{dL}, \mathrm{AST}$ : $47 \mathrm{U} / \mathrm{L}$, ALT: $25 \mathrm{U} / \mathrm{L}$, Sodium: $135 \mathrm{mmol} / \mathrm{L}$, Potassium $4.78 \mathrm{mmol} / \mathrm{L}$, Calcium: $8.9 \mathrm{mg} / \mathrm{dL}$, Albumin: $2.3 \mathrm{~g} / \mathrm{dL}$, Globulin: $4.8 \mathrm{~g} / \mathrm{dL}$, IgA: $3480 \mathrm{mg} / \mathrm{dL}$, IgG: $413 \mathrm{mg} / \mathrm{dL}$, IgM: $19.3 \mathrm{mg} / \mathrm{dL}$, IgE: $24.4 \mathrm{mg} / \mathrm{dL}$, Prostate specific antigen (PSA): $0.6 \mu \mathrm{g} / \mathrm{L}$, WBC: $5,900 \times 10^{9} / \mathrm{L}$, Hemoglobin: $12.4 \mathrm{~g} / \mathrm{dL}$, Platelet: $179 \times 10^{9} / \mathrm{L}$, erythrocyte sedimentation rate: $120 \mathrm{~mm} / \mathrm{h}$. Thoracic computed tomography of the patient revealed fracture of the ribs. Head x-ray revealed lytic lesions. Whole-body bone scintigraphy showed heterogeneous osteoblastic activity in sternum and heterogeneous osteoblastic activity in T9-L1 vertebrae (Figure 3). When the peripheral blood smear was evaluated, rouleaux formation was present; the leukocyte formula was consistent with the hemogram, and the lymphocyte morphology was normal. Erythrocytes were normocytic and

Received: June 26, 2019 Accepted: July 09, 2019 Published online: October 31, 2019

Correspondence: Damla Çağla Patır. Sağlık Bilimleri Üniversitesi, İzmir Tepecik SUAM, İç Hastalıkları Kliniği, 35180 Yenişehir, Konak, İzmir, Türkiye. Tel: +90539 - 2730592 e-mail: damlapatir@yahoo.com 
hypochromic. Bone marrow aspiration and biopsy was performed (Figure 4). Bone marrow biopsy revealed plasma cell infiltration at a rate of $60 \%$. Biopsy results were reported to be compatible with multiple myeloma. The patient was initiated melphalan and methylprednisolone. He was discharged with recommendation of hematology outpatient management.

Bone lesions in multiple myeloma are usually associated with an imbalance of osteolytic and osteoblastic activity, which generally favors osteolytic activity. Molecules such as Interleukin (IL)-1, IL-6, sIL-6R, tumor necrosis factor alpha $(\mathrm{TNF}-\alpha)$, macrophage inflammatory protein 1 alpha (MIP-1 $\alpha$ ), neurofilament light (NF-ligB) ligand receptor activator, MIP-1 $\alpha$, dickkopf1, osteoprotegerin, and parathyroid hormonerelated protein mediate the osteolytic process. ${ }^{[4]}$ The pathogenesis of sclerotic lesions in multiple

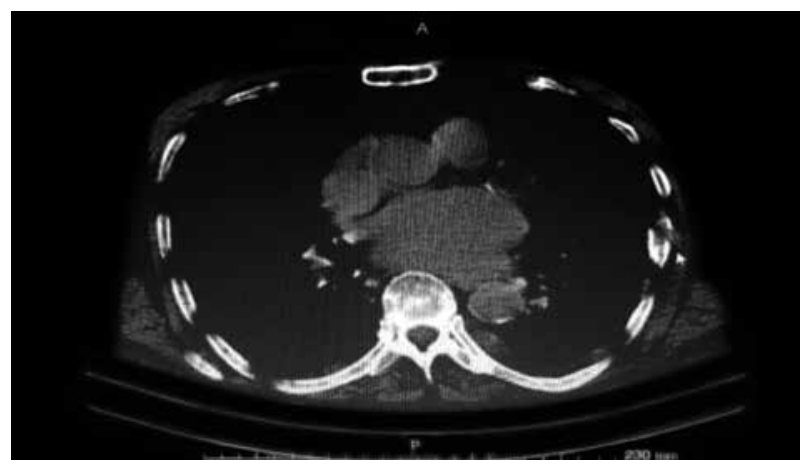

Figure 1. Fracture of the ribs.

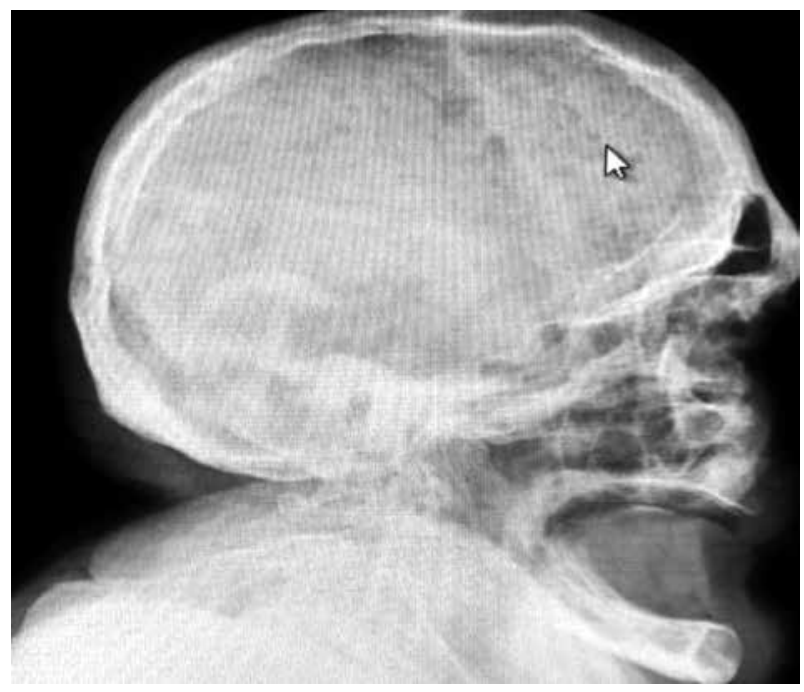

Figure 2. Lytic lesions. myeloma is still unclear. Lacy et al. ${ }^{[5]}$ suggested that the separation of osteoclastic and osteoblastic activity or the increased activity of plateletderived growth factors were possible underlying causes of sclerotic lesions in multiple myeloma. Most patients with sclerotic bone lesions described in the literature have lambda chain monoclonal gammopathy. Although sclerotic lesions are more common in POEMS syndrome, they can also be observed in patients treated for multiple myeloma. Criteria for the diagnosis of POEMS syndrome include monoclonal plasma cell disorder, peripheral neuropathy, bone lesions, organomegaly, endocrinopathy (excluding diabetes mellitus or hypothyroidism), edema, typical skin changes, and papilledema. ${ }^{6]}$ Our case did not meet the criteria of POEMS syndrome. Diffuse osteosclerosis due to plasma

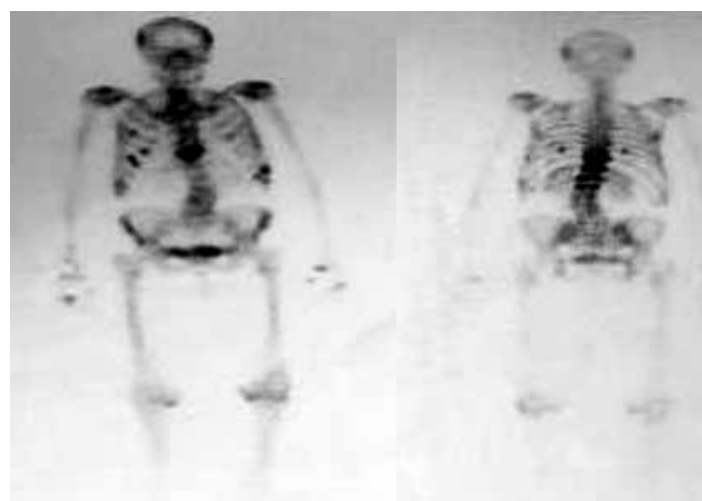

Figure 3. Heterogeneous (whole body bone scintigraphy) osteoblastic activity.

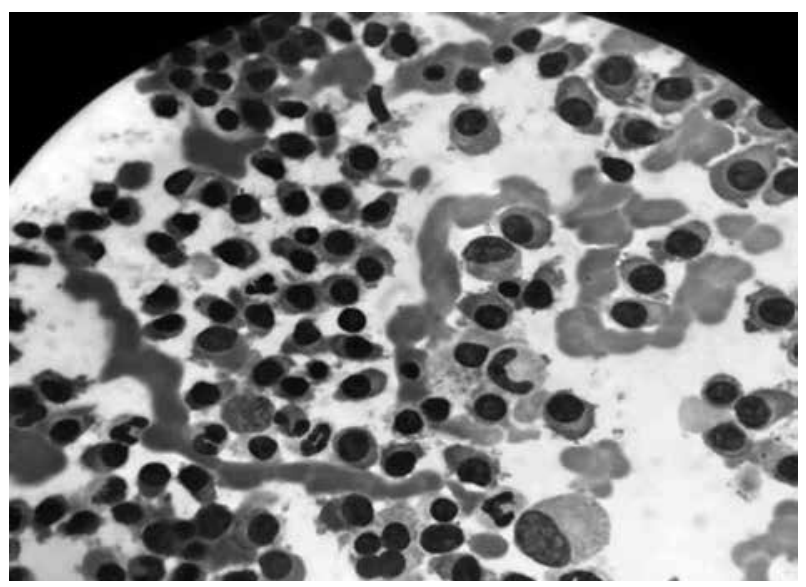

Figure 4. Bone marrow aspiration. 
cell myeloma occurs in less than 3\% of patients. The combination of both lytic and sclerotic lesions is very rare.

\section{Declaration of conflicting interests}

The authors declared no conflicts of interest with respect to the authorship and/or publication of this article.

\section{Funding}

The authors received no financial support for the research and/or authorship of this article.

\section{REFERENCES}

1. Tosi P, Gamberi B, Giuliani N. Biology and treatment of multiple myeloma. Biol Blood Marrow Transplant
2006;12:81-6.

2. Greer JP, Kinney MC, Loughran TP Jr. T cell and NK cell lymphoproliferative disorders. Hematology Am Soc Hematol Educ Program 2001:259-81.

3. Hsu HL, Liu KL. Osteosclerotic myeloma with POEMS syndrome. QJM 2010;103:993-4.

4. Casciato DA, editor. Manual of clinical oncology. 6th ed. Philadelphia: LWW; 2009.

5. Lacy MQ, Gertz MA, Hanson CA, Inwards DJ, Kyle RA. Multiple myeloma associated with diffuse osteosclerotic bone lesions: a clinical entity distinct from osteosclerotic myeloma (POEMS syndrome). Am J Hematol 1997;56:288-93.

6. Kyle RA, Rajkumar SV. Criteria for diagnosis, staging, risk stratification and response assessment of multiple myeloma. Leukemia 2009;23:3-9. 